\title{
Production of Pectinase from Bacillus sonorensis MPTD1
}

\section{Anju Mohandas', \\ Sindhu Raveendran ${ }^{1 *}$, \\ Binod Parameswaran', Amith Abraham', \\ Raj S. R. Athira ${ }^{1,2}$, Anil \\ Kuruvilla Mathew' \\ and Ashok Pandey ${ }^{3}$}

\section{'Microbial Processes and Technology Division, CSIR-National Institute for Interdisciplinary Science and Technology (CSIR-NIIST), 695019 \\ Trivandrum, India \\ ${ }^{2}$ Academy of Scientific and Innovative Research (AcSIR), CSIR-NIIST, 695019 \\ Trivandrum, India \\ ${ }^{3}$ CSIR-Indian Institute of Toxicology \\ Research (CSIR-IITR), 226001 \\ Lucknow, India}

Received: August 18, 2017 Accepted: February 5, 2018

\footnotetext{
*Corresponding author:

Phone +914712515426;

Fax: +914712491712 ;

E-mail:sindhurgcb@gmail.com,

sindhufax@yahoo.co.in
}

ORCID IDs: 0000-0001-7026-0615 (Mohandas), 0000-0002-7368-3792 (Raveendran), 0000-0001-7295-5509 (Parameswaran), 0000-0003-4228-3849 (Abraham), 0000-0002-8469-0365 (Athira), 0000-0002-5335-3382 (Mathew), 0000-0003-1626-3529 (Pandey)

Paper was presented at the 7th International Forum on Industrial Bioprocessing - IFIBiop 2017, May 21-24, 2017, Wuxi, PR China

\begin{abstract}
SUMMARY
Seven isolates from spoiled fruits and vegetables were screened for pectinase production using pectin agar plates and the most efficient bacterial strain, MPTD1, was identified as Bacillus sonorensis. Optimisation of various process parameters was done using Plackett-Burman and Box-Behnken designs and it was found that parameters like yeast extract, $\mathrm{K}_{2} \mathrm{HPO}_{4}$, incubation time, $\mathrm{NaNO}_{3}$ and $\mathrm{KCl}$ have a negative impact on pectinase production. Parameters like $\mathrm{pH}$ and $\mathrm{MgSO}_{4}$ and pectin mass fractions have a positive impact on pectinase production. The maximum obtained enzyme activity was $2.43(\mu \mathrm{M} / \mathrm{mL}) / \mathrm{min}$. This is the first report on pectinase production by Bacillus sonorensis.
\end{abstract}

Key words: pectinase, fermentation optimization, Bacillus sonorensis

\section{INTRODUCTION}

Pectin is a major component of the primary cell wall of all land plants. Pectic substances are colloidal polysaccharides, with galacturonic acid backbone linked by a (1-4) linkage (1). Pectin acts as the inducer for the production of pectinolytic enzymes by microbial systems (2). Pectinases degrade complex pectin to monogalacturonic acid molecules. They are classified into seven classes: pectinesterase (EC 3.1.1.11), polygalacturonase (EC 3.2.1.15), galacturan 1,4-a-galactouronidase (EC 3.2.1.67), exopoly-a-galactouronosidase (EC 3.2.1.82), endopectate lyase (EC 4.2.2.2), exopectate lyase (EC 4.2.2.9) and endopectin lyase (EC 4.2.2.10) (3) based on their activity. Bacillus sp., Erwinia sp. and Pseudomonas sp. are major producers of pectinases (4). Pectinase contributes to $25 \%$ of the global food enzyme market (5). Since pectinase is one of the most important industrial enzymes, several research activities are going on for the production of pectinases with improved activities, properties as well as utilisation of cost-effective substrates for better process economics.

Several reports are available on pectinase production from fungi like Aspergillus, Rhizopus and Penicillium (6). Most of the pectinase production is carried out by adopting solid-state fermentation (SSF) strategy. Acidic pectinases find wider range of applications in food industry, while alkaline pectinases find applications in various industrial processes (7). Pectinolytic enzymes are present on rotten fruit and vegetable wastes because they are an essential component of the natural decaying process. Pectinase has a wide variety of applications such as fruit juice clarification in fruit processing industry (1). Alkaline pectinase produced by Bacillus licheniformis can be used for the treatment of effluent generated by vegetable and food processing industries (8), protoplast isolation (9), bleaching of paper, or in textile industry for degumming of jute, sun hemp, flax, ramie and coconut fibre (10). The addition of pectinase together with cellulases, hemicellulases and proteinases to the tea-leaf fermenting bath increases the tea quality index by $5 \%$ (11). Use of pectinase in diverse applications indicates the importance of pectinase for green process.

The target of this research is to evaluate the potential of a locally isolated pectinase-producing strain from decayed fruits and vegetables. Optimization of culture conditions using submerged fermentation (SmF) was also investigated for maximum enzyme production. 


\section{MATERIALS AND METHODS}

\section{Sample collection and isolation}

Spoiled fruits and vegetables were collected from nearby fruit shops in Pappanamcode, Kerala, India, and samples of 1 $\mathrm{g}$ were mixed in $100 \mathrm{~mL}$ of normal saline, serially diluted from $10^{-1}$ to $10^{-6}$ ratio. A volume of $100 \mu \mathrm{L}$ of each diluted sample was inoculated in pectin agar medium and incubated at 37 ${ }^{\circ} \mathrm{C}$ for $48 \mathrm{~h}$ (12). About 50 microorganisms were isolated on pectin agar plate. Serial dilution up to $10^{-6}$ was carried out to obtain isolated colonies. The pectinolytic activity was detected by visualizing a clear zone around the colony using Gram's iodine flooding method.

\section{Selection and screening of microorganisms}

Colonies from serially diluted plates with different morphologies were selected; each purified colony was maintained on pectin agar plates and stored at $4{ }^{\circ} \mathrm{C}$. Pectin agar medium was prepared with (in $\mathrm{g} / \mathrm{L}$ ): $\mathrm{NaNO}_{3} 1.0, \mathrm{KCl} 1.0, \mathrm{~K}_{2} \mathrm{HPO}_{4}$ 1.0, $\mathrm{MgSO}_{4} 0.5$, yeast extract 0.5 , pectin 10 and agar 20 with pH adjusted to 7.0 (13). All chemicals were obtained from HiMedia, Mumbai, India. Subsequent subculturing was done for proper maintenance of the culture and further experimental studies.

Pectinase-producing microorganisms were primarily screened by plating the colonies on pectin agar plates incubated at $37^{\circ} \mathrm{C}$ for $48 \mathrm{~h}$. Gram's iodine assay was carried out for further screening by adding Gram's iodine solution to pectin agar plates with colonies of sample organisms; after 5 min of incubation with an intermittent gentle shaking the plates were washed with distilled water and clear zones around colonies were observed (14).

\section{Enzyme extraction and polygalacturonase assay by dinitrosalicylic acid method}

Enzyme was extracted by centrifuging the culture at $6000 \times g$ (centrifuge model C-24BL; REMI, Maharashtra, India) for 10 min at $4{ }^{\circ} \mathrm{C}$, the supernatant was stored at $-20{ }^{\circ} \mathrm{C}$ and the pellet was discarded.

The pectinase activity of the enzyme extract was assayed based on the modified method of Miller (15). The 3,5-dinitrosalicylic acid (DNS; Merck, Mumbai, India) in alkaline solution was reduced to 3-amino-5-nitrosalicylic acid. Pectinase activity was measured by the estimation of the amount of galacturonic acid with the DNS method using $1 \%$ citrus pectin (Merck) as a substrate and mono-D-galacturonic acid (Merck) as a standard. The culture broth was centrifuged, and $0.5 \mathrm{~mL}$ of the culture supernatant and $0.5 \mathrm{~mL}$ of pectin were added. The tubes were incubated for $30 \mathrm{~min}$ at $50^{\circ} \mathrm{C}$ in a water bath (JULABO GmbH, Seelbach, Germany). A volume of $1.5 \mathrm{~mL}$ of DNS was added and the tubes were incubated in boiling water bath for $5 \mathrm{~min}$. Then the samples were diluted and the colour intensity was measured at $540 \mathrm{~nm}$ (spectrophotometer model UV-1601; Shimadzu, Kyoto, Japan). The pectinase activity (in $(\mu \mathrm{M} / \mathrm{mL}$ )/min) was calculated by the following equation:

$$
\text { Pectinase activity }=\frac{c(\text { monogalacturonic acid }) \cdot \text { dilution factor } \cdot 1000}{\frac{212.15}{t(\text { incubation })}}
$$

\section{Identification of pectinase-producing bacterial isolate MPTD1}

The pectinase-producing bacterial isolate was identified on the basis of 16S rRNA gene sequence analysis. The universal primers used for the amplification of $16 \mathrm{~S}$ rDNA were: 1) $27 \mathrm{~F} \mathrm{5'AGAGTTTGATCCTGGCTCAG-3'} \mathrm{and} \mathrm{2)} \mathrm{1492R} \mathrm{5'GGT-}$ TACCTTGTTACGACTT- 3 ' and final concentrations of the reagents were: $\mathrm{MgCl}_{2} 1 \mathrm{mM}$, dNTP $200 \mu \mathrm{M}$, primers 100 pmol and DNA 50 ng. The BioRad Thermal Cycler (Bio-Rad, San FrancisCo, CA, USA) was used for the amplification of DNA with the following PCR cycles: initial cycle at $94^{\circ} \mathrm{C}$ for $3 \mathrm{~min}$, followed by 35 cycles at $94^{\circ} \mathrm{C}$ for $1 \mathrm{~min}, 55^{\circ} \mathrm{C}$ for $1 \mathrm{~min}, 72^{\circ} \mathrm{C}$ for $2 \mathrm{~min}$, and final extension of $5 \mathrm{~min}$ at $72{ }^{\circ} \mathrm{C}$. The amplified product was checked on $1 \%$ agarose gel and the sample was purified using Gene JET-PCR purification kit (Thermo Scientific, Vilnius, Lithuania). Purified 16S rDNA product was sequenced at CSIR-NIIST sequencing facility centre, Trivandrum, India. The isolate was identified by comparing the similarity of amplified DNA sequence with other sequences in databases like National Centre for Biotechnology Information (NCBI) GenBank (16) and EzTaxon (17). Most similar sequences from a database were collected and a multiple sequence alignment was performed using ClustalW2 (18). A phylogenetic tree was constructed from the alignment file using MEGA5 (19). The phylogeny across the data was analysed by UPGMA (20) and the reliability of the phylogram was checked by Bootstrap analysis (1000 replicates) (21). 16S rDNA sequence data were used to identify the selected bacterial isolate from spoiled fruit and vegetable samples. A PCR product of approx. $1.5 \mathrm{~kb}$ was amplified and sequenced. The highly similar sequences were recovered from the database as reference sequences and aligned with the 16S rDNA sequences of the pectinase-producing isolate MPTD1. Phylogenetic analysis was conducted with pectinase-producing isolate MPTD1 and reference sequences collected from the database. Evolutionary distances were calculated using the maximum composite likelihood method and expressed in the units of the number of base substitutions per site.

\section{Optimization of various process parameters for pectinase production}

\section{Plackett-Burman design}

Optimization of various process parameters for pectinase production in submerged fermentation was done by adopting Plackett-Burman design (22), using different mass fractions of $\mathrm{NaNO}_{3^{\prime}} \mathrm{K}_{2} \mathrm{HPO}_{4^{\prime}} \mathrm{KCl}, \mathrm{MgSO}_{4^{\prime}}$ pectin, yeast extract, $\mathrm{pH}$ and incubation time. These eight parameters were used at two levels (higher and lower) to choose the prime factors for 
pectinase production by the selected strain (23). Details are presented in Table 1.

\section{Response surface methodology (Box-Behnken design)}

The prime factors for pectinase production were selected from the Placket-Burman design and optimized by adopting response surface methodology. The selected parameters were: $\mathrm{MgSO}_{4^{\prime}}$ pectin mass fractions and $\mathrm{pH}$. There were a total of 15 runs with three parameters (24). Details are presented in Table 2.

\section{RESULTS AND DISCUSSION}

Isolation and primary screening

of pectinolytic organisms

Among 50 isolated microorganisms, about seven strains were found to have pectinolytic activity. Positive isolates were selected based on the clearance zone in Gram's iodine assay. Fig. 1 shows pectinolytic microorganisms on pectin agar plates after flooding with iodine reagent.

Table 1. Plackett-Burman design for optimization of various process parameters affecting pectinase production

\begin{tabular}{|c|c|c|c|c|c|c|c|c|c|c|}
\hline \multirow{2}{*}{$\begin{array}{c}\text { Run } \\
\text { number }\end{array}$} & \multicolumn{6}{|c|}{$w / \%$} & \multirow{2}{*}{$\mathrm{pH}$} & \multirow{2}{*}{$\frac{t \text { (incubation) }}{\mathrm{h}}$} & \multirow{2}{*}{$\frac{\text { Enzyme activity }}{(\mu \mathrm{M} / \mathrm{mL}) / \mathrm{min}}$} & \multirow{2}{*}{$\frac{N(\text { colony })}{\text { CFU/mL }}$} \\
\hline & $\mathrm{KCl}$ & $\mathrm{K}_{2} \mathrm{HPO}_{4}$ & $\mathrm{MgSO}_{4}$ & YE & $\mathrm{NaNO}_{3}$ & Pectin & & & & \\
\hline 1 & 2 & 0.5 & 0.25 & 0.5 & 2 & 15 & 8 & 24 & 1.30 & $1.05 \cdot 10^{5}$ \\
\hline 2 & 0.5 & 0.5 & 0.25 & 0.5 & 0.5 & 5 & 6 & 24 & 0.94 & $3 \cdot 10^{5}$ \\
\hline 3 & 2 & 0.5 & 0.75 & 0.5 & 0.5 & 5 & 8 & 60 & 1.43 & $2.5 \cdot 10^{7}$ \\
\hline 4 & 0.5 & 2 & 0.75 & 0.5 & 2 & 5 & 6 & 24 & 1.02 & $2.5 \cdot 10^{6}$ \\
\hline 5 & 0.5 & 0.5 & 0.25 & 2 & 2 & 15 & 6 & 60 & 1.77 & $4.52 \cdot 10^{4}$ \\
\hline 6 & 0.5 & 2 & 0.25 & 0.5 & 0.5 & 15 & 8 & 60 & 1.69 & $3.5 \cdot 10^{7}$ \\
\hline 7 & 2 & 2 & 0.25 & 2 & 2 & 5 & 8 & 24 & 1.68 & $6.55 \cdot 10^{8}$ \\
\hline 8 & 2 & 2 & 0.25 & 2 & 0.5 & 5 & 6 & 60 & 0.74 & $4.21 \cdot 10^{8}$ \\
\hline 9 & 0.5 & 2 & 0.75 & 2 & 0.5 & 15 & 8 & 24 & 2.44 & $6.9 \cdot 10^{8}$ \\
\hline 10 & 2 & 2 & 0.75 & 0.5 & 2 & 15 & 6 & 60 & 2.33 & $6 \cdot 10^{6}$ \\
\hline 11 & 2 & 0.5 & 0.75 & 2 & 0.5 & 15 & 6 & 24 & 1.03 & $1.5 \cdot 10^{7}$ \\
\hline 12 & 0.5 & 0.5 & 0.75 & 2 & 2 & 5 & 8 & 60 & 2.13 & $3.65 \cdot 10^{7}$ \\
\hline
\end{tabular}

$\mathrm{YE}=$ yeast extract

Table 2. Box-Behnken design for optimization of various process parameters affecting pectinase production

\begin{tabular}{|c|c|c|c|c|c|c|c|}
\hline \multirow{2}{*}{$\begin{array}{c}\text { Run } \\
\text { number }\end{array}$} & \multirow{2}{*}{$\begin{array}{l}\text { Point } \\
\text { type }\end{array}$} & \multirow{2}{*}{ Block } & \multirow{2}{*}{$\mathrm{pH}$} & \multicolumn{2}{|c|}{$w / \%$} & \multirow{2}{*}{$\begin{array}{l}\text { Enzyme activity } \\
(\mu \mathrm{M} / \mathrm{mL}) / \mathrm{min}\end{array}$} & \multirow{2}{*}{$\frac{N(\text { colony })}{\text { CFU } / \mathrm{mL}}$} \\
\hline & & & & Pectin & $\mathrm{MgSO}_{4}$ & & \\
\hline 1 & 2 & 1 & 8 & 25 & 1 & 1.22 & $5 \cdot 10^{7}$ \\
\hline 2 & 2 & 1 & 9 & 20 & 0.75 & 1.42 & $3 \cdot 10^{7}$ \\
\hline 3 & 2 & 1 & 7 & 20 & 0.75 & 1.53 & $1 \cdot 10^{8}$ \\
\hline 4 & 0 & 1 & 8 & 20 & 0.88 & 1.48 & $91 \cdot 10^{6}$ \\
\hline 5 & 2 & 1 & 8 & 25 & 0.75 & 1.32 & $1 \cdot 10^{7}$ \\
\hline 6 & 2 & 1 & 9 & 20 & 1 & 1.54 & $46 \cdot 10^{6}$ \\
\hline 7 & 0 & 1 & 8 & 20 & 0.88 & 1.82 & $3 \cdot 10^{7}$ \\
\hline 8 & 2 & 1 & 7 & 25 & 0.88 & 2.16 & $61 \cdot 10^{6}$ \\
\hline 9 & 2 & 1 & 7 & 20 & 1 & 1.30 & $79 \cdot 10^{7}$ \\
\hline 10 & 0 & 1 & 8 & 20 & 0.88 & 1.32 & $67 \cdot 10^{6}$ \\
\hline 11 & 2 & 1 & 7 & 15 & 0.88 & 1.34 & $11 \cdot 10^{6}$ \\
\hline 12 & 2 & 1 & 8 & 15 & 0.75 & 1.55 & $8 \cdot 10^{7}$ \\
\hline 13 & 2 & 1 & 9 & 25 & 0.88 & 1.29 & $11 \cdot 10^{8}$ \\
\hline 14 & 2 & 1 & 9 & 15 & 0.88 & 1.12 & $8 \cdot 10^{7}$ \\
\hline 15 & 2 & 1 & 8 & 15 & 1 & 1.14 & $125 \cdot 10^{7}$ \\
\hline
\end{tabular}




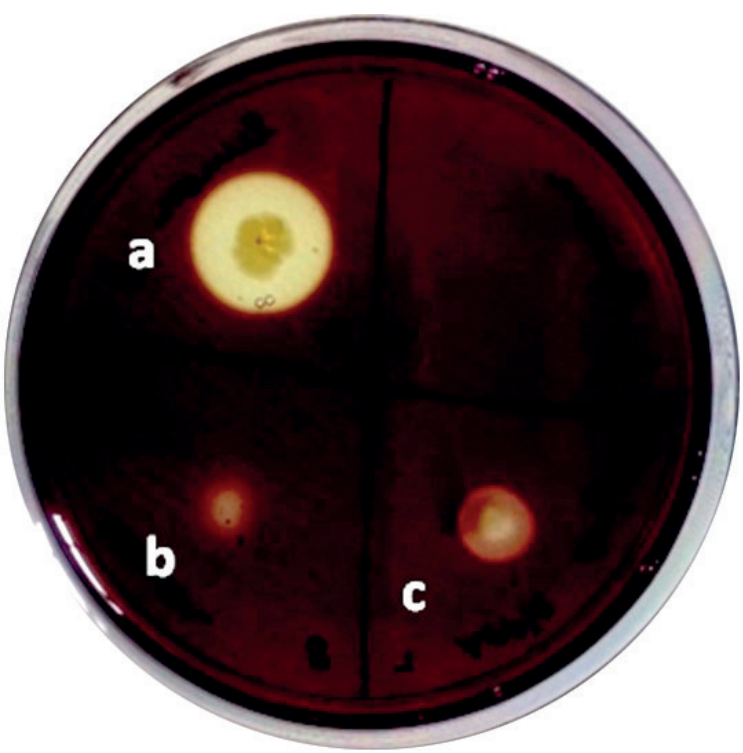

Fig. 1. Pectinase-producing microorganisms showing clear zones on pectin agar plates after Gram's iodine staining: MPTD1 (a), MPTD4 (b) and MPTD6 (c)

\section{Secondary screening of pectinolytic microorganisms} based on DNS assay

Seven strains showed pectinolytic activity on pectin agar medium. Submerged fermentation was done to select the potent strain. High pectinase activity in short time was obtained with MPTD1. Maximum enzyme activity obtained was $2.1(\mu \mathrm{M} / \mathrm{mL}) / \mathrm{min}$ of MPTD1, so it was selected for further optimization studies. Enzyme activity of other isolates (MPTD2, MPTD3, MPTD4, MPTD5, MPTD6 and MPTD7) was 1.2, 1.1, 1.5, 1.3, 1.4 and $1.3(\mu \mathrm{M} / \mathrm{mL}) / \mathrm{min}$, respectively.

\section{Strain identification based on 165 rDNA sequence data}

Comparing the 16s rDNA sequence data of isolated MPTD1 with those of the organisms presented in the databases GenBank and EzTaxon, it was established that it has 99 $\%$ similarity with Bacillus sonorensis sp. In the dendrogram, all Bacillus sonorensis isolates were clustered together with very high bootstrap value, where the sequence of Bacillus subtilis was used as an outgroup (Fig. 2). The 16S rDNA sequence of pectinase-producing Bacillus sonorensis MPTD1 was deposited in NCBI with GenBank ID MG774437.

\section{Optimization of pectinase production}

Determination of significant process parameters by Plackett-Burman design

Estimation of monogalacturonic acid yield based on Plackett-Burman design indicates that higher $\mathrm{pH}, \mathrm{MgSO}_{4}$ and pectin mass fractions have a stronger positive effect, while $\mathrm{K}_{2} \mathrm{HPO}_{4}, \mathrm{NaNO}_{3}$ and yeast extract mass fractions and incubation time have a weaker impact on pectinase production by MPTD1 strain. High $\mathrm{KCl}$ mass fraction had a negative effect on pectinase production. An identical observation was reported earlier by Thiagarajan et al. (25) for xylanase production by Aspergillus fumigatus MKU1. Exact molecular mechanism for this effect is not known. These positive factors were found to have stronger effect on pectinase production and were selected for further optimization. Maximum pectinase activity of $240(\mu \mathrm{M} / \mathrm{mL}) / \mathrm{min}$ was observed in run number 9 (Table 1).

The results depicted in Pareto chart (Fig. 3) indicate that $\mathrm{MgSO}_{4}$ and pectin mass fractions and $\mathrm{pH}$ were found to have a stronger effect on pectinase production and were further optimized using Box-Behnken design.

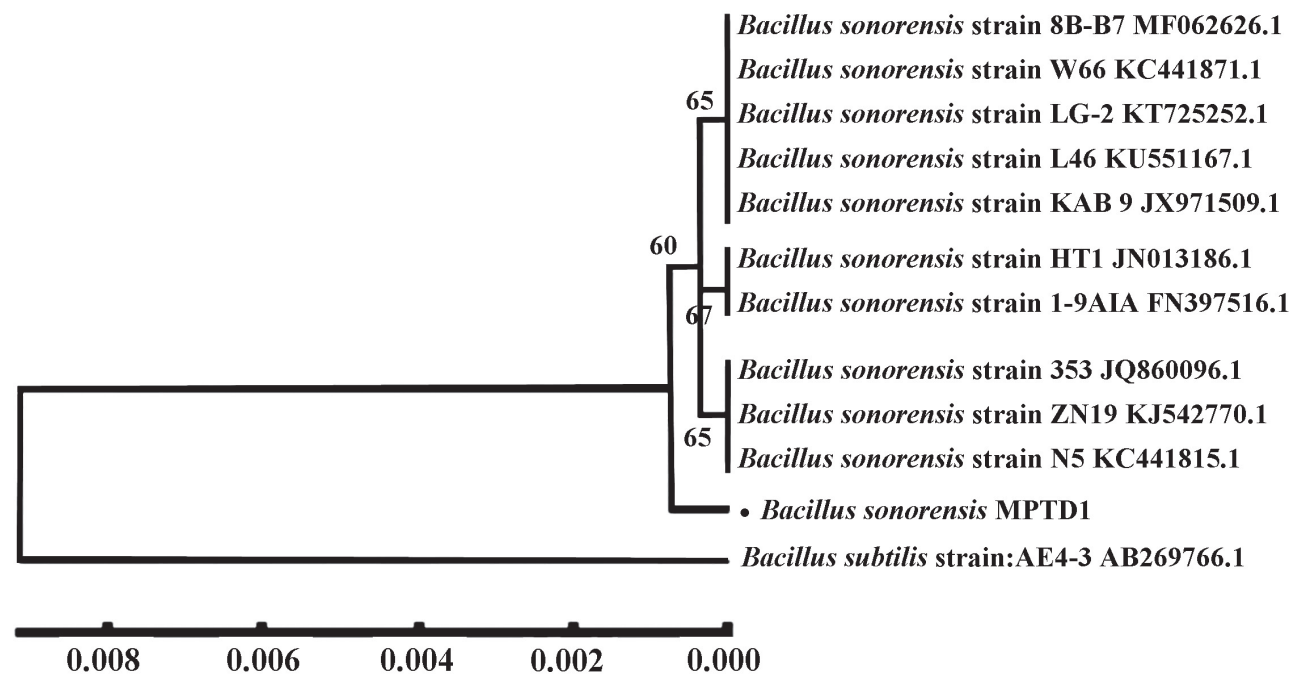

Fig. 2. Phylogenetic tree expressing the relationship between pectinase-producing bacterial strain MPTD1 with reference strains based on the $16 \mathrm{~S}$ rDNA sequences. Bacillus subtilis is used as an outgroup. Numbers shown in each node are confidence level generated from 1000 bootstraps. Scale bar is nucleotide substitution per sequence position 


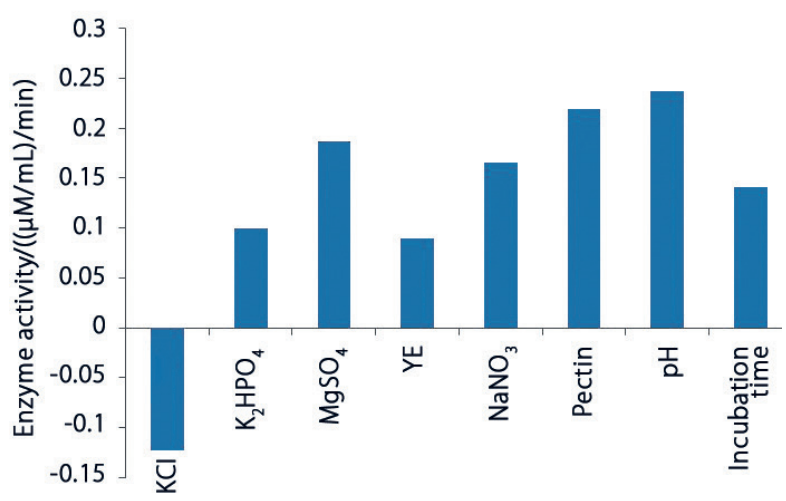

Fig. 3. Pareto chart showing significant parameters affecting pectinase activity

Box-Behnken design experiment to find the interactions between the significant process parameters

The results indicate that the maximum enzyme activity of $2.16(\mu \mathrm{M} / \mathrm{mL}) / \mathrm{min}$ was observed in run number 8 (Table 2 ). The maximum pectinase activity was $2.16(\mu \mathrm{M} / \mathrm{mL}) / \mathrm{min}(26)$.

Figs. $4 \mathrm{a}$ and $4 \mathrm{~b}$ show surface and contour plots of the effect of interactions between $\mathrm{MgSO}_{4}$ and pectin mass fractions on pectinase activity. At low mass fractions of pectin (15-18 $\%)$ and $\mathrm{MgSO}_{4}(0.75-0.8 \%)$, the pectinase activity was low. It

a)

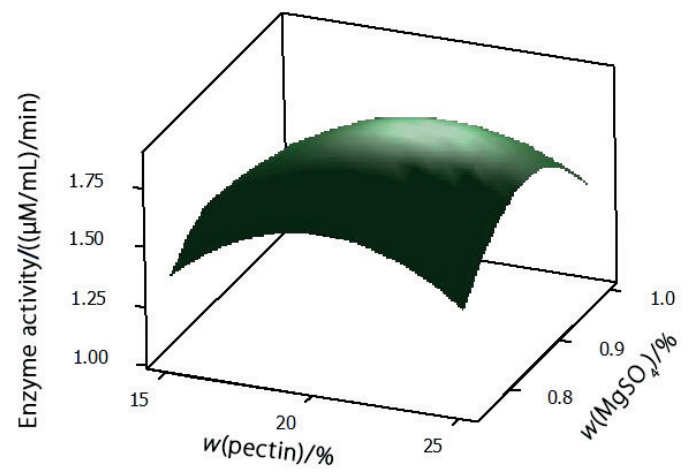

b)

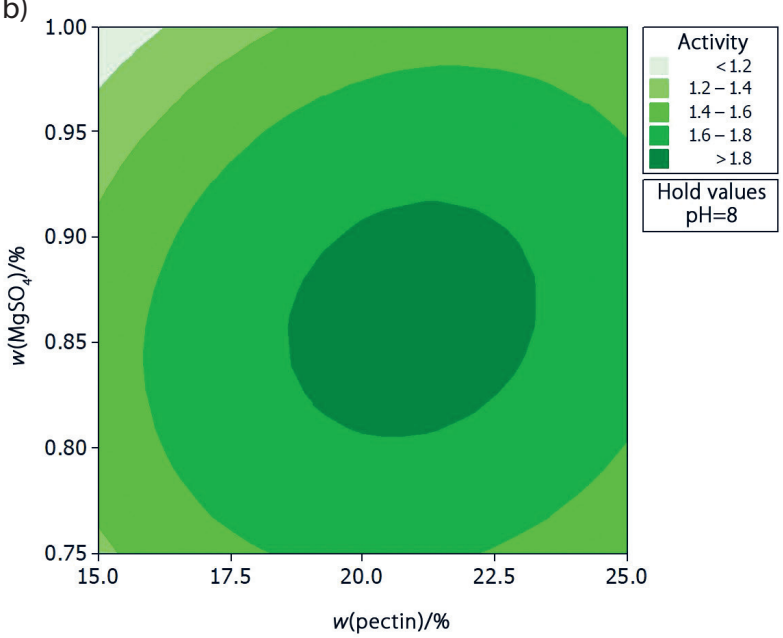

Fig. 4. Surface (a) and contour (b) plots showing the effect of interactions of $\mathrm{MgSO}_{4}$ and pectin mass fractions on pectinase activity increased with an increase of pectin and $\mathrm{MgSO}_{4}$ mass fractions. Maximum pectinase activity of $1.8(\mu \mathrm{M} / \mathrm{mL}) / \mathrm{min}$ was observed at medium mass fractions of pectin (19-23\%) and $\mathrm{MgSO}_{4}$ (0.08-0.09\%). Pectinase production decreased at higher mass fractions of pectin and $\mathrm{MgSO}_{4}$. Different results were reported by Mehta et al. (27) where maximum enzyme production was observed with $0.5 \%$ of pectin.

Figs. $5 \mathrm{a}$ and $5 \mathrm{~b}$ show surface and contour plots of the effect of interactions between $\mathrm{pH}$ and pectin mass fractions on pectinase activity. At low mass fractions of pectin, the pectinase activity was low. It increased with the increase of pectin mass fraction and maximum pectinase production of 1.8 $(\mu \mathrm{M} / \mathrm{mL}) / \mathrm{min}$ was observed at high mass fractions of pectin (20-25\%). At low to middle value of $\mathrm{pH}$ (2.5-8.0), pectinase production was high and it decreased with an increase of $\mathrm{pH}$ (8.0-9.0). Akinyemi et al. (28) reported maximum pectinase activity at $\mathrm{pH}=8.0$ when using Bacillus megaterium and Bacillus bataviensis.

a)

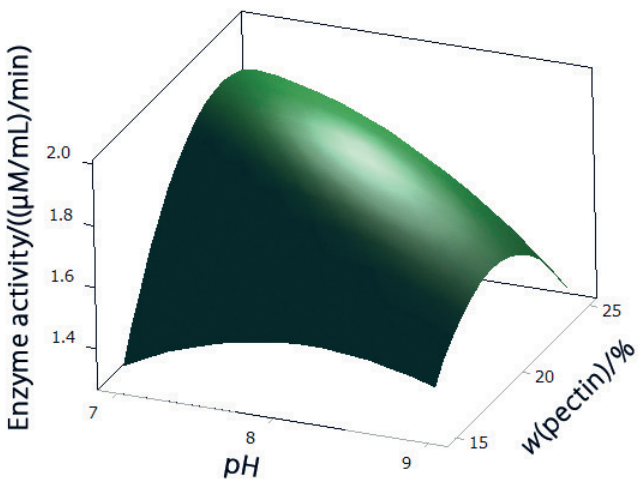

b)

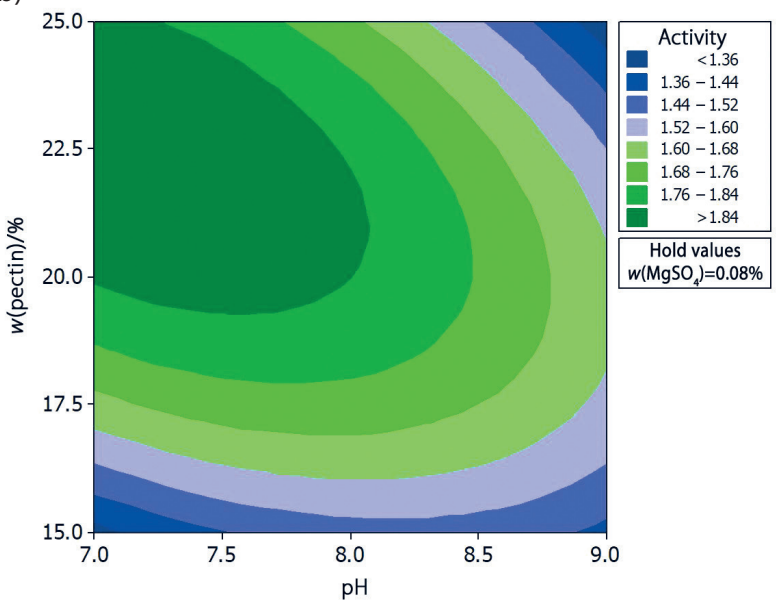

Fig. 5. Surface (a) and contour (b) plots showing the effect of interactions of $\mathrm{pH}$ and pectin mass fraction on enzyme production

Figs. $6 \mathrm{a}$ and $6 \mathrm{~b}$ show surface and contour plots of the effect of interactions between $\mathrm{pH}$ and $\mathrm{MgSO}_{4}$ mass fraction on pectinase activity. At low mass fractions of $\mathrm{MgSO}_{4}$ (0.75-0.9 $\%)$ and low $\mathrm{pH}(7.0-8.0)$ the pectinase production was high $(1.8(\mu \mathrm{M} / \mathrm{mL}) / \mathrm{min})$. It decreased with the increase of $\mathrm{pH}$ and $\mathrm{MgSO}_{4}$ mass fraction. At higher $\mathrm{pH}$ values (8.0-9.0) and higher mass fractions of $\mathrm{MgSO}_{4}(0.9-1.0 \%)$ the pectinase production 
a)

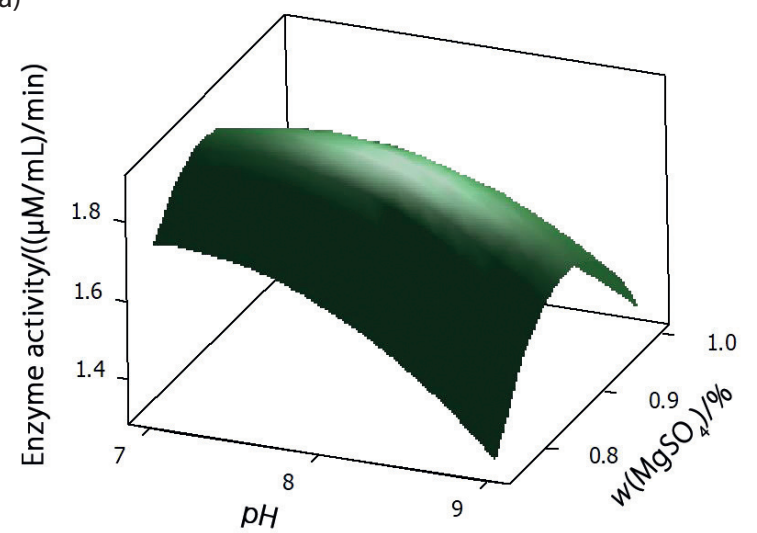

b)

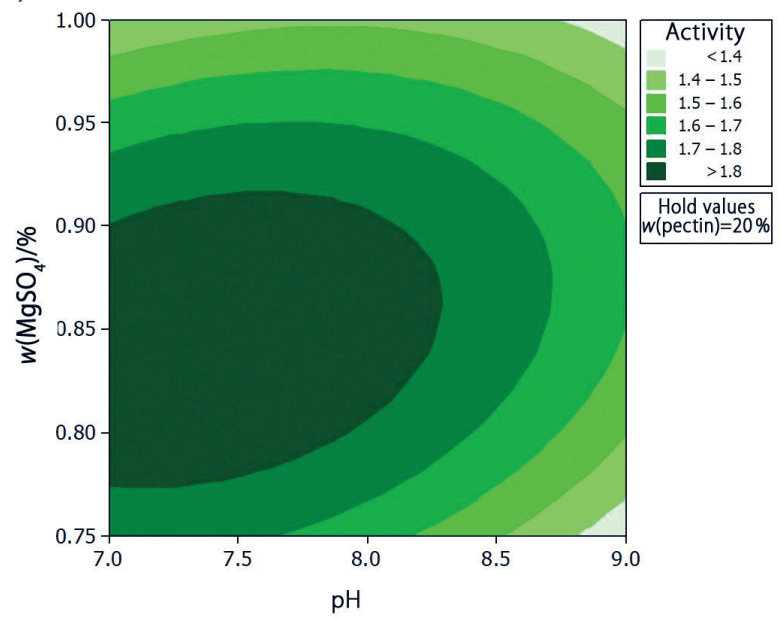

Fig. 6. Surface (a) and contour (b) plots showing the effect of interactions of $\mathrm{MgSO}_{4}$ mass fraction and $\mathrm{pH}$ on enzyme production

was low (1.4 ( $\mu \mathrm{M} / \mathrm{mL}) / \mathrm{min})$. An identical observation was reported earlier by Mehta et al. (27) for pectinase production from a soil isolate where maximum pectinase activity was observed at $\mathrm{pH}=6.0-8.0$.

\section{CONCLUSIONS}

Identifying the significant factors affecting pectinase production using experimental design is essential for the production of enzymes on a large scale. Bacillus sonorensis MPTD1, isolated from decayed fruit and vegetables, showed highest pectinase activity, so it was explored for optimisation of various process parameters affecting pectinase production by adopting a Plackett-Burman and Box-Behnken designs. Optimization studies revealed that $\mathrm{pH}$ and $\mathrm{MgSO}_{4}$ and pectin mass fractions have a significant role in pectinase production. It is clear from Pareto chart that parameters like yeast extract, dipotassium hydrogen phosphate, incubation time and sodium nitrate have a lower impact on pectinase production, while potassium chloride has a negative impact on pectinase production by Bacillus sonorensis. Maximum pectinase production of $2.434(\mu \mathrm{M} / \mathrm{mL}) / \mathrm{min}$ was observed with $2 \% \mathrm{~K}_{2} \mathrm{HPO}_{4^{\prime}} 0.75 \% \mathrm{MgSO}_{4^{\prime}} 2 \%$ yeast extract, $0.5 \% \mathrm{NaNO}_{3}$ and $15 \%$ pectin, at $\mathrm{pH}=8.0$ and incubation time of $24 \mathrm{~h}$. Optimization using Box-Behnken design revealed that maximum pectinase production was observed under the following conditions: $\mathrm{pH}=7.0,25 \%$ pectin and $0.88 \% \mathrm{MgSO}_{4}$ mass fractions. Fine tuning can improve the process. This is the first report on pectinase production by Bacillus sonorensis.

\section{ACKNOWLEDGEMENTS}

Sindhu Raveendran acknowledges Department of Science and Technology for sanctioning a project under DST WOS-B scheme. Abraham Amith acknowledges KSCSTE, India, for providing postdoctoral fellowship. Kuruvilla Anil Mathew acknowledges Kerala Biotechnology Commission (KBC, KSCSTE), Kerala, India, for providing postdoctoral fellowship. Raj S. R. Athira acknowledges Academy of Scientific and Innovative Research (AcSIR) for providing resources to carry out doctoral studies.

\section{REFERENCES}

1. Tapre AR, Jain RK. Pectinases: Enzymes for fruit processing industry. Int Food Res J. 2014;21(2):447-53.

2. Ali J, Jaffery SA, Assad Q, Hussain A, Abid H, Gul F. Optimization of pectinase enzyme production using sour oranges peel (Citrus aurantium L.) as substrate. Pak J Biochem Mol Biol. 2010;43(3):126-30.

3. Garg G, Singh A, Kaur A, Singh R, Kaur J, Mahajan R. Microbial pectinases: An ecofriendly tool of nature for industries. 3 Biotech. 2016;6:47.

https://doi.org/10.1007/s13205-016-0371-4

4. Esmail R, Yazaji S, Balaa BAI. Isolation, production and characterisation of extracellular pectin lyase from Bacillus subtilis. Adv Environ Biol. 2013;7(13):3917-24.

5. Thangaratham T, Manimegalai G. Optimization and production of pectinase using agro waste by solid state and submerged fermentation. Int J Curr Microbiol Appl Sci. 2014;3(9):357-65.

6. Mrudula S, Anitharaj R. Pectinase production in solid-state fermentation by Aspergillus niger using orange peel as substrate. Global J Biotechnol Biochem. 2011;6(2):64-71.

7. Rebello S, Anju M, Aneesh EM, Sindhu R, Binod P, Pandey A. Recent advancements in the production and application of microbial pectinases: An overview. Rev Environ Sci Biotechnol. 2017;16(3):381-94.

https://doi.org/10.1007/s11157-017-9437-y

8. Rehman HU, Siddique NN, Aman A, Nawaz MA, Baloch AH, Qader SAU. Morphological and molecular based identification of pectinase producing Bacillus licheniformis from rotten vegetable. J Genetic Eng Biotechnol. 2015;13(2):139-44. https://doi.org/10.1016/j.jgeb.2015.07.004

9. Power JB, Cocking EC. Isolation of leaf protoplsts: Macromolecule uptake and growth substance response. J Exp Bot. 1970;21(1):64-70. https://doi.org/10.1093/jxb/21.1.64 
10. Mehraj Pasha K, Anuradha P, Subbarao D. Applications of pectinases in industrial sector. Int J Pure Appl Sci Technol. 2013;16(1):89-95.

11. Biscaro Pedrolli D, Costa Monteiro A, Gomes E, Cano Carmona E. Pectin and pectinases: Production, characterization and industrial application of microbial pectinolytic enzymes. Open Biotechnol J. 2009;3:9-18. https://doi.org/10.2174/1874070700903010009

12. Sharma M, Rathore M, Sharma N, Dayama S, Jogpal B, Dashora K, Sharma A. Isolation of pectinolytic bacteria from rotten tomato. J Medical Dental Research. 2011;1(3):158-61.

13. Mukesh Kumar DJ, Saranya GM, Suresh K, Andal Priyadharshini D, Rajakumar R, Kalaichelvan PT. Production and optimization of pectinase from Bacillus sp. MFW7 using cassava waste. Asian J Plant Sci Res. 2012;2(3):369-75.

14. Priya V, Sashi V. Pectinase enzyme producing microorganisms. Int J Sci Res Pub. 2014;4(3):1-4.

15. Miller GL. Use of dinitrosalicylic acid reagent for determination of reducing sugar. Anal Chem. 1959;31(3):426-8. https://doi.org/10.1021/ac60147a030

16. Benson DA, Clark K, Karsch-Mizrachi I, Lipman DJ, Ostell J, Sayers EW. GenBank. Nucleic Acids Res. 2015;43(D1):D30-5. https://doi.org/10.1093/nar/gku1216

17. Chun J, Lee JH, Jung Y, Kim M, Kim S, Kim BK, Lim YW. EzTaxon: A web-based tool for the identification of prokaryotes based on 16S ribosomal RNA gene sequences. Int J Syst Evol Microbiol. 2007;57:2259-61. https://doi.org/10.1099/ijs.0.64915-0

18. Larkin MA, Blackshields G, Brown NP, Chenna R, McGettigan PA, McWilliam H, et al. Clustal W and Clustal X version 2.0. Bioinformatics. 2007;23(21):2947-8. https://doi.org/10.1093/bioinformatics/btm404

19. Tamura K, Dudley J, Nei M, Kumar S. MEGA4: Molecular Evolutionary Genetics Analysis (MEGA) software version 4.0. Mol Biol Evol. 2007;24(8):1596-9. https://doi.org/10.1093/molbev/msm092
20. Sneath PHA, Sokal RR. Numerical taxonomy. The principles and practice of numerical classification. San Francisco, CA, USA: Freeman Co; 1973.

21. Felsenstein J. Confidence limits on phylogenies: An approach using the bootstrap. Evolution. 1985;39(4):783-91. https://doi.org/10.1111/j.1558-5646.1985.tb00420.x

22. Madu JO, Nkem T, Emuebie OR, Isreal JE, Kayode AF. Physicochemical factors influencing pectinolytic enzyme produced by Bacillus licheniformis under submerged fermentation. Nat Sci. 2014;12(8):110-6.

23. El-Refai HA, El-Helow ER, Amin MA, Sallam LA, Salem HAA. Application of multi-factorial experimental designs for optimization of biotin production by a Rhizopus nigricans strain. J Am Sci. 2010;6(6):179-87.

24. Tekindal MA, Bayrak H, Ozkaya B, Genc Y. Box-Behnken experimental design in factorial experiments: The importance of bread for nutrition and health. Turk J Field Crops. 2012;17(2):115-23.

25. Thiagarajan S, Jeya M, Gunasekaran P. Improvement of xylanase production in solid state fermentation by alkali-tolerant Aspergillus fumigatus MKU1 using a fractional factorial design. Indian J Exp Biol. 2005; 43(10):887-91.

26. Gonçalves DB, Teixeira JA, Soares Bazzolli DM, de Queiroz MV, Fernandes de Araújo E. Use of response surface methodology to optimize production of pectinases by recombinant Penicillium griseoroseum T20. Biocatalysis Agri Biotechnol. 2012;1(2):140-6.

https://doi.org/10.1016/j.bcab.2011.09.002

27. Mehta SA, Mitali R, Nilofer S, Nimisha P. Optimization of physiological parameters for pectinase production from soil isolates and its applications in fruit juice clarification. J Environ Res Develop. 2013;7(4A):1539-46.

28. Akinyemi BT, Buraimoh OM, Ogunrinde OO, Amund OO. Pectinase production by Bacillus megaterium, Bacillus bataviensis, and Paenibacillus sp. isolated from decomposing wood residues in the Lagos lagoon. J Tropical Life Sci. 2017;7(3):204-7. https://doi.org/10.11594/jtls.07.03.03 